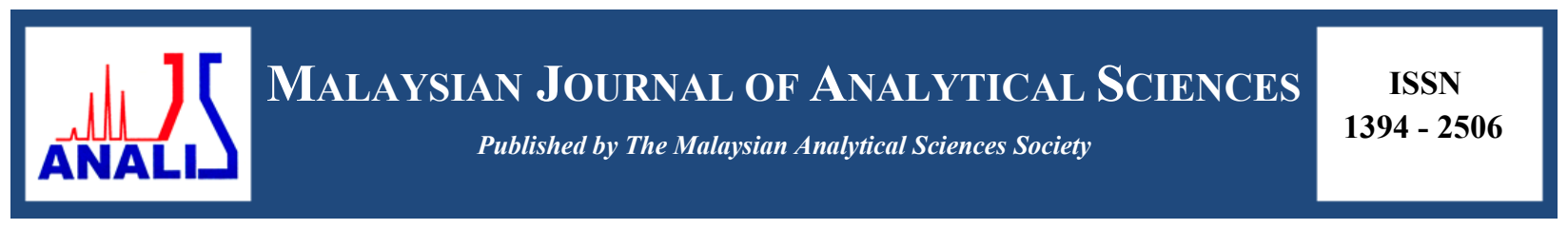

\title{
CHARACTERIZATION AND DEACIDIFICATION OF ACIDIC PETROLEUM CRUDE OIL UTILIZING METAL OXIDE CATALYST SUPPORTED ON ALUMINA AND AMMONIATED POLYETHYLENE GLYCOL SOLUTION
}

\author{
(Pencirian dan Penyahasidan Minyak Mentah Petroleum Menggunakan Mangkin Logam Oksida \\ Disokong Alumina dan Larutan Ammonia Polietilena Glikol) \\ Nurasmat Mohd Shukri, Jafariah Jaafar*, Wan Azelee Wan Abu Bakar, Zaiton Abdul Majid \\ Department of Chemistry, Faculty of Science, \\ Universiti Teknologi Malaysia, 81310 UTM Johor Bahru, Johor, Malaysia \\ *Corresponding author: jafariah@kimia.fs.utm.my
}

Received: 20 September 2016; Accepted: 16 May 2017

\begin{abstract}
The presence of naphthenic acid (NA) in petroleum crude oil may cause serious corrosion problem for refinery processing equipment. In this work, an alternative method to remove NA is investigated based on the catalytic deacidification reaction to achieve the target of lowering the total acid number (TAN) as required by PETRONAS to be less than 1. Ammoniated polyethylene glycol $\left(\mathrm{NH}_{3}\right.$-PEG) was formulated as a deacidifying agent with various concentrations ranging from $100-1000$ $\mathrm{mg} / \mathrm{L}$ for crude oil. Cerium oxide based catalyst supported on alumina was synthesized via wet impregnation method and characterized using X-ray diffraction spectroscopy (XRD), Brunauer-Emmett-Teller (BET) and thermogravimetry analysisdifferential thermal analysis (TGA-DTA). Parameters such as amount of basic chemical dosing, type of metal oxides, catalyst calcination temperature and reusability of catalyst on the removal of NA was studied. The results showed the TAN value for crude oil was reduced by $70.6 \%$ to a TAN of $0.74 \mathrm{mg} \mathrm{KOH} / \mathrm{g}$ by using $1000 \mathrm{mg} / \mathrm{L}$ of $\mathrm{NH}_{3}-\mathrm{PEG}$ dosing aids by $\mathrm{Ce} / \mathrm{Al}_{2} \mathrm{O}_{3}$ catalyst calcined at $1000^{\circ} \mathrm{C}$.
\end{abstract}

Keywords: total acid number, naphthenic acid, metal oxide catalyst, ammoniated polyethylene glycol, alumina

\section{Abstrak}

Kehadiran asid naftenik (NA) dalam minyak mentah boleh menyebabkan masalah hakisan yang serius kepada peralatan pemprosesan penapisan. Di dalam kajian ini, satu kaedah alternatif untuk menyingkir NA telah disiasat berdasarkan tindak balas penyahasidan pemangkin untuk mencapai sasaran jumlah nombor asid (TAN) kurang daripada 1 seperti yang dikehendaki PETRONAS. Larutan ammonia polietilena glikol $\left(\mathrm{NH}_{3}-\mathrm{PEG}\right)$ telah diformulakan sebagai ejen penyahasidan dengan pelbagai kepekatan antara $100-1000 \mathrm{mg} / \mathrm{L}$. Mangkin serium oksida disokong dengan alumina telah disintesis menggunakan kaedah pengisi tepuan basah dan dicirikan menggunakan spektroskopi pembelauan sinar-X (XRD), Brunauer-Emmett-Teller (BET) dan analisis termogravimetri - analisis pengkamiran terma (TGA-DTA). Parameter seperti jumlah dos kimia bes, jenis logam oksida, suhu pengkalsinan mangkin dan kebolehgunaan mangkin terhadap penyingkiran NA telah dikaji. Hasil kajian menunjukkan nilai TAN bagi minyak mentah telah dikurangkan sebanyak $70.6 \%$ kepada TAN $0.74 \mathrm{mg} \mathrm{KOH} / \mathrm{g}$ dengan menggunakan $1000 \mathrm{mg} / \mathrm{L}$ dos $\mathrm{NH}_{3}$-PEG dibantu oleh mangkin $\mathrm{Ce} / \mathrm{Al}_{2} \mathrm{O}_{3}$ dikalsinkan pada $1000{ }^{\circ} \mathrm{C}$.

Kata kunci: nombor jumlah asid, asid naftenik, mangkin, ammonia polietilena glikol, alumina 


\section{Nurasmat et al: CHARACTERIZATION AND DEACIDIFICATION OF ACIDIC PETROLEUM CRUDE OIL UTILIZING METAL OXIDE CATALYST SUPPORTED ON ALUMINA AND AMMONIATED POLYETHYLENE GLYCOL SOLUTION}

\section{Introduction}

The initial concern about naphthenic acid corrosion dates back to the previous century, and it keeps drawing the attention of refineries until today [1]. Naphthenic acid (NA) is a complex mixture of cyclic or acyclic aliphatic organic compounds characterized by a carboxyl reactive group [2] and constitutes about $50 \mathrm{wt} . \%$ of the total acidic compounds in crude oil [3].Total acid number (TAN) refers to the amount of NA found in the crude oil and was measured using ASTM D664 method. TAN represents milligram of KOH per gram liquid needed to neutralize $1 \mathrm{~g}$ of acid present in the sample. If the acidic species in the petroleum cannot be removed during the refinement, it will influence the quality of the final product, causing problems, equipment failures, and environmental pollution. Several efforts are focused on the development of the current approaches to refine acidic crudes by blending with non-acidic crudes so that the TAN of the blend is no higher than about $0.5 \mathrm{mg} \mathrm{KOH} / \mathrm{g}$ [4]. The drawback of this approach is that it limits the amount of acidic crude that can be processed. The acidic crudes can be treated with inorganic bases such as potassium and sodium hydroxide to neutralize the acids [5]. This approach, however, forms an emulsion which is very difficult to break and undesirably leaves potassium or sodium in the treated crude. Catalytic removal of NA has been studied for many years. It has been reported that transition metal catalyst could reduce the acidity of crude oil under hydrogen atmosphere but, this process consumes large amounts of hydrogen [6] and it has not been commercialized yet. In order to solve this problem, the catalytic deacidification process was investigated in this work by using different metal oxides as catalyst supported on alumina to assist in the deacidification process together with the $\mathrm{NH}_{3}-\mathrm{PEG}$ as basic chemical agent.

\section{Materials}

\section{Materials and Methods}

All the materials were purchased from QRëC ${ }^{\mathrm{TM}}$ and used without further treatment. 2-propanol and toluene were used as extraction solvents. Ammonia solution 28\% mixed with polyethylene glycol (MW 300, 400 and 600) were used as deacidifying agents. Phenolphthalein indicator solution, $1 \%$ in ethanol was used as an indicator in the deacidification process. Potassium hydroxide pellets and barium hydroxide were used as titrants. The feedstock used in this study was crude oil obtained from Petronas Penapisan Melaka, Malaysia labelled as crude B with a TAN of $2.52 \mathrm{mg} \mathrm{KOH} / \mathrm{g}$.

\section{Preparation of $0.4 \% \mathrm{NH}_{3}$-PEG}

Ammonia solution $(40 \mathrm{~mL})$ was added dropwise into a sample bottle containing $9.96 \mathrm{~mL}$ polyethylene glycol. The mixture of $\mathrm{NH}_{3}$-PEG was vigorously stirred using a magnetic bar for an hour. The reaction of $\mathrm{NH}_{3}$ with $\mathrm{PEG}$ to form $\mathrm{NH}_{3}$-PEG was hastened by soaking the bottle in an ice bath. The solution, which was then ready for blending with the crude oil, was set aside in a dark bottle to avoid sunlight penetration.

\section{Catalyst preparation}

The catalyst was synthesized by wet impregnation method according to the report by Toemen et al. [7].The required amount of cerium nitrate in a beaker was dissolved with a small amount of distilled water. The solution was then mixed via continuous stirring using a magnetic bar for 30 minutes at ambient temperature to homogenize the mixture. Alumina beads with diameters of between 4 to $5 \mathrm{~mm}$ were used as support material. The support was dipped into the catalyst solutions for 24 hours and then transferred onto an evaporating dish lined with glass wool. Subsequently, it was aged in an oven at $80-90{ }^{\circ} \mathrm{C}$ for 24 hours to eliminate moisture and allow coating of the metal on the surface of the supported catalysts.

This was followed by calcination in the furnace at $400,700,900$ and $1000{ }^{\circ} \mathrm{C}$ for 5 hours using a ramp rate of 10 ${ }^{\circ} \mathrm{C} / \mathrm{min}$ to eliminate all metal precursors, excess water and impurities. The developed catalysts were analyzed by BET, FESEM-EDX and XRD to characterize the physicochemical properties of the catalyst.

\section{Catalysts characterization}

Potential catalyst was characterized by several techniques to study its physicochemical properties. The information obtained is highly useful in order to understand the relationship between the properties and its catalytic performance towards the deacidification activity. In this research, the characterization techniques used were X-ray diffraction spectroscopy (XRD), Brunauer-Emmett-Teller (BET) and thermogravimetry analysis-differential thermal analysis (TGA-DTA). 
Total acid number (TAN) determination

An amount $0.2 \mathrm{~g}$ crude B was measured and placed in a titration beaker. As much as $40 \mathrm{~mL}$ of the titration solvent, which is a mixture of toluene: 2-propanol: distilled water (50:49.5:0.5) was poured into the crude oil sample in the titration beaker. After that, $100 \mathrm{ppm}$ of $4 \% \mathrm{NH}_{3}-\mathrm{PEG}$ solution together with the prepared catalyst was added into $0.1-0.15 \mathrm{~g}$ crude oil sample. The solution was heated to $35-40{ }^{\circ} \mathrm{C}$ to stimulate the catalyst in the mixture. The petroleum crude oil sample was then titrated with potassium hydroxide solution $(0.01 \mathrm{~mol} / \mathrm{L})$. Total acid number value for crude $\mathrm{B}(\mathrm{TAN}=2.52 \mathrm{mg} \mathrm{KOH} / \mathrm{g})$ was determined by semi-micro color indicator titration method. The indicator used was phenolphthalein solution $(0.1 \mathrm{~mL})$, the end-point for the titration method was indicated when the stable red color was observed. The titration method was performed on crude B before and after the catalytic deacidification technology. In order to express the results, TAN value of the sample was calculated in milligrams of potassium hydroxide per gram of sample (mg KOH/g) by using the equation below (Equation 1):

$$
\mathrm{TAN}=\frac{56.1 \times \mathrm{cx}\left(\mathrm{V}_{\mathrm{KOH}}-\mathrm{V}_{\mathrm{B}}\right)}{\mathrm{m}}
$$

where $c$ is the concentration of the standard volumetric potassium hydroxide solution (in $\mathrm{mol} / \mathrm{L}$ ), $\mathrm{V}_{\mathrm{KOH}}$ is the volume of titrant required for the determination (in $\mathrm{mL}$ ), $\mathrm{V}_{\mathrm{B}}$ is the volume of titrant required for the blank test, (in $\mathrm{mL}$ ), and $\mathrm{m}$ is the mass of the test portion (in gram).

\section{Results and Discussion}

Catalytic deacidification of Crude B: Effect of different molecular weight of PEGs

The deacidification activities for crude B increased significantly when using PEG with molecular weights of 300, 400, 600 and 1500 as shown in Figure 1. This observation is proven by the decrease in TAN values of crude B along these PEGs. Lower TAN values of $1.68 \mathrm{mg} \mathrm{KOH} / \mathrm{g}$ were obtained for crude B by using both MW PEG of 600 and 1500. These results showed that the deacidification activities for crude B were decreased by using these PEGs. However, in this work, PEG with MW 600 was chosen as the solvent for deacidification agent due to higher percentage of NA removal for crude B and its cheaper cost compared to other PEGs.

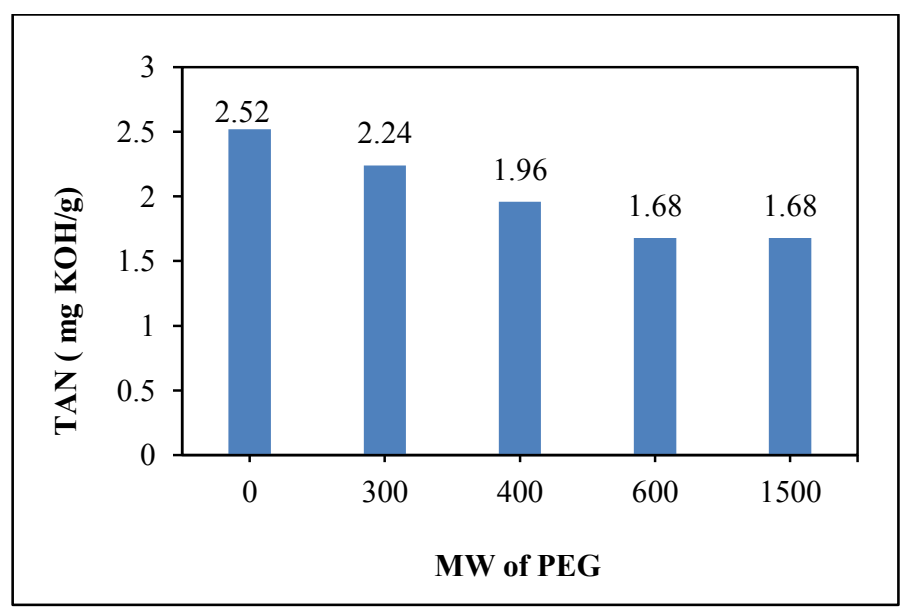

Figure 1. Effect of the different molecular weights of PEG on TAN values of crude B. [Initial TAN value for crude B $(2.52 \mathrm{mg} \mathrm{KOH} / \mathrm{g})]$

\section{Effect of different basic chemical dosing}

The deacidification performances of different dosing amount of $\mathrm{NH}_{3}-\mathrm{PEG}$ in the range of $100-2500 \mathrm{mg} / \mathrm{L}$ were compared in order to select a suitable dosing amount for removal of naphthenic acid in the crude oil sample and the result is presented in the Figure 2. 


\section{Nurasmat et al: CHARACTERIZATION AND DEACIDIFICATION OF ACIDIC PETROLEUM CRUDE OIL UTILIZING METAL OXIDE CATALYST SUPPORTED ON ALUMINA AND AMMONIATED POLYETHYLENE GLYCOL SOLUTION}

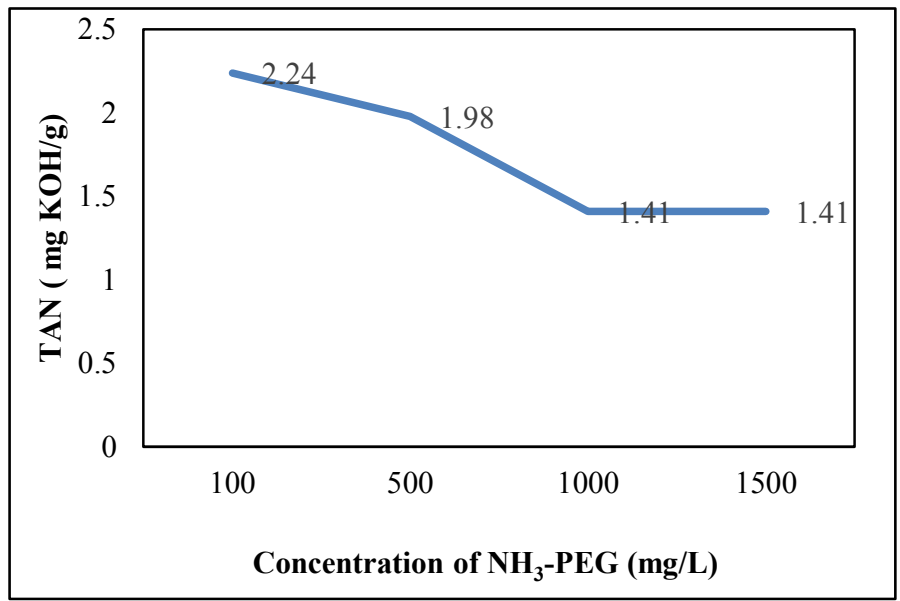

Figure 2. Effect of different dosing amount of $\mathrm{NH}_{3}-\mathrm{PEG}$ on the TAN value.

It could be seen from Figure 2, the TAN number of crude B decreased with increasing dosing amounts of $\mathrm{NH}_{3}$-PEG. When the dosing rose to $1000 \mathrm{mg} / \mathrm{L}$ the TAN number was decreased to $1.41 \mathrm{mg} \mathrm{KOH} / \mathrm{g}$ and after that the curve become flat. The amount of dosing employed in the study should be appropriate enough to react with the NA in the crude oil $\mathrm{B}$, because huge amounts of $\mathrm{NH}_{3}$-PEG may form a stable emulsion, which would probably stabilize the $\mathrm{NA}$ in crude $\mathrm{B}$ and reduce the deacidification reaction. Even though high concentration of $\mathrm{NH}_{3}-\mathrm{PEG}$ was added, there is no change of the TAN value. This explained that using $1000 \mathrm{mg} / \mathrm{L}$ is sufficient to deacidify the acid in crude B because if the concentration was increased more than $1000 \mathrm{mg} / \mathrm{L}$ it will cause operational difficulties and waste.

\section{Effect of different metal oxides and calcination temperatures of catalyst}

In the preparation of the catalyst, the types of metal oxide catalyst and calcination temperatures are determinant of catalyst activity. The catalytic deacidification was carried out under reaction temperature ranging between 35 to $40^{\circ} \mathrm{C}$ with addition of $100-1000 \mathrm{mg} / \mathrm{L}$ of $\mathrm{NH}_{3}$ - $\mathrm{PEG}$ dosing in the presence of $\mathrm{Ce} / \mathrm{Al}_{2} \mathrm{O}_{3}, \mathrm{Zn} / \mathrm{Al}_{2} \mathrm{O}_{3}$ and $\mathrm{Sn} / \mathrm{Al}_{2} \mathrm{O}_{3}$ catalysts calcined at different temperatures of 400,700 and $1000^{\circ} \mathrm{C}$ for $5 \mathrm{~h}$. Figure 3 portrays the effect of different metal oxide catalysts prepared at different calcination temperatures towards the catalytic deacidification process.

A noticeable difference was recorded for the catalytic deacidification process fulfilling the expected target of TAN to be less than one. An increase in the calcination temperature for all catalysts from 400 to $1000{ }^{\circ} \mathrm{C}$ caused a decrease of the TAN value for crude $\mathrm{B}$. For these studies, the $\mathrm{Ce} / \mathrm{Al}_{2} \mathrm{O}_{3}$ catalyst calcined at $1000{ }^{\circ} \mathrm{C}$ gave the lowest value of TAN of $0.74 \mathrm{mg} \mathrm{KOH} / \mathrm{g}$ followed by $\mathrm{Sn} / \mathrm{Al}_{2} \mathrm{O}_{3}$ catalyst calcined at $1000{ }^{\circ} \mathrm{C}(\mathrm{TAN}=1.68 \mathrm{mg} \mathrm{KOH} / \mathrm{g})$ and $\mathrm{Zn} / \mathrm{Al}_{2} \mathrm{O}_{3}$ catalyst calcined at $1000{ }^{\circ} \mathrm{C}$ with a TAN of $1.41 \mathrm{mg} \mathrm{KOH} / \mathrm{g}$. As for the $\mathrm{Ce} / \mathrm{Al}_{2} \mathrm{O}_{3}$ catalyst, the calcination temperature below than $1000{ }^{\circ} \mathrm{C}$ cannot reduce the TAN value below than one due to incomplete metal oxide formation and the amorphous properties of this catalyst which produced less amount of basic surface active sites available for the catalytic deacidification reaction. However, an increase in the calcination temperature up to 1000 ${ }^{\circ} \mathrm{C}$ for this catalyst managed to reduce the TAN below than one due to its polycrystallinity properties as shown in XRD data which generated a larger amount of total basic surface active sites led to a successful catalytic deacidification reaction. Furthermore, excellent redox properties of $\mathrm{CeO}$ due to the very fast reduction of $\mathrm{Ce}^{4+} / \mathrm{Ce}^{3+}$ as reported by Ayastuy et al. [8] results in the formation of oxygen vacancies at the surface, making the NA removal more efficient. Thus, $\mathrm{Ce}$ calcined at $1000{ }^{\circ} \mathrm{C}$ was chosen as the catalyst to be further optimized in this study.

\section{Reusability testing over $\mathrm{Ce} / \mathrm{Al}_{2} \mathrm{O}_{3}$ catalyst}

The potential $\mathrm{Ce} / \mathrm{Al}_{2} \mathrm{O}_{3}$ catalyst calcined at $1000{ }^{\circ} \mathrm{C}$ was tested several times under optimum reaction conditions in order to study the reusability of this catalyst. It was tested by using the same catalyst until the catalyst was deactivated. After one catalytic reaction was completed, the catalyst was rinsed with 2-propanol to remove any adsorbed naphthenic acid compounds. The catalyst was then dried in an oven at $80{ }^{\circ} \mathrm{C}$ and re-used for the second reaction. The process was repeated for the next consecutive run. Figure 4 shows the plot of reusability testing over 
$\mathrm{Ce} / \mathrm{Al}_{2} \mathrm{O}_{3}$ catalyst. It can be seen that the TAN value was maintained $(0.74 \mathrm{mg} \mathrm{KOH} / \mathrm{g})$ until the fifth cycle. However, the catalyst started to deactivate (spent catalyst) at the sixth testing as a slight decrease in the activity is seen as indicated by the increasing TAN value to $0.84 \mathrm{mg} \mathrm{KOH} / \mathrm{g}$.
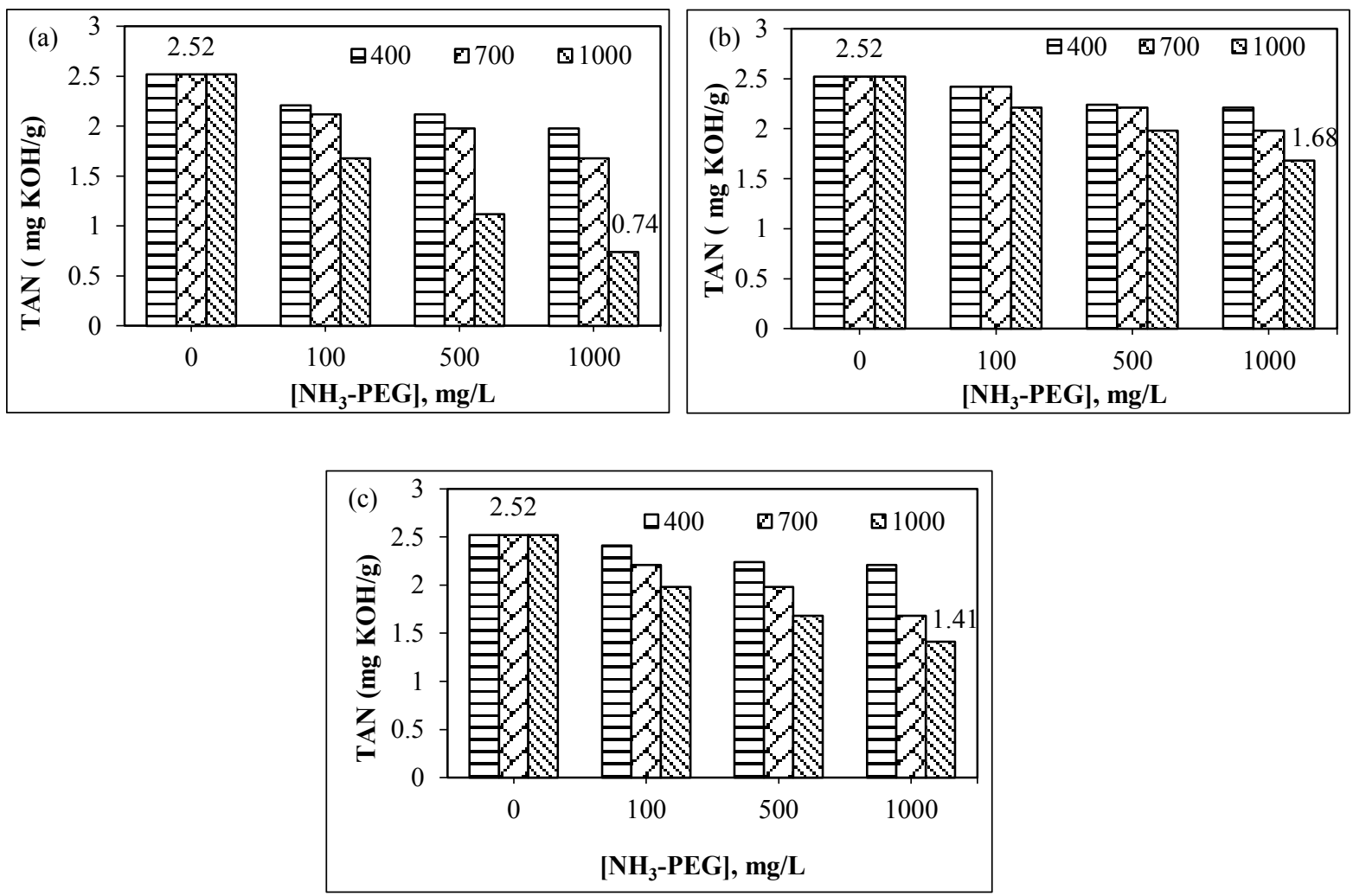

Figure 3. Effect of a) Ce, ) $\mathrm{Zn}$ and c) Sn catalysts supported on alumina calcined at 400,700 and $1000{ }^{\circ} \mathrm{C}$ on the reduction of TAN value

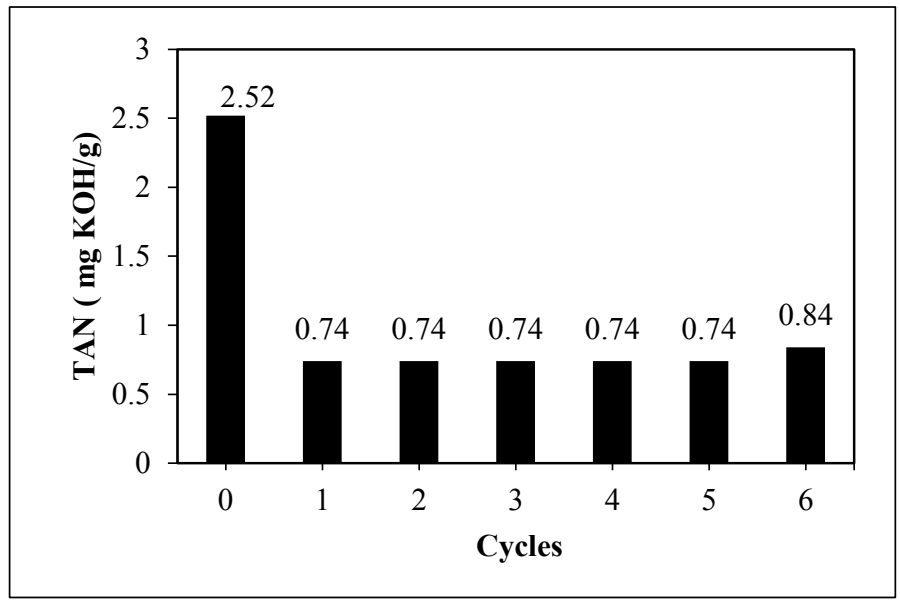

Figure 4. TAN value for six cycles of catalytic deacidification. Reaction conditions: Catalyst $=\mathrm{Ce} / \mathrm{Al}_{2} \mathrm{O}_{3}$, calcination temperature of catalyst: $1000{ }^{\circ} \mathrm{C}$. 


\section{Nurasmat et al: CHARACTERIZATION AND DEACIDIFICATION OF ACIDIC PETROLEUM CRUDE OIL UTILIZING METAL OXIDE CATALYST SUPPORTED ON ALUMINA AND AMMONIATED POLYETHYLENE GLYCOL SOLUTION}

\section{Characterization of the potential catalyst: TGA-DTA}

After aging the catalysts which had been prepared by wetness impregnation method in an oven for 24 hours at 80 $90{ }^{\circ} \mathrm{C}$, the catalyst was analyzed by using TGA-DTA. Figure 5 shows the TGA thermogram of $\mathrm{Ce} / \mathrm{Al}_{2} \mathrm{O}_{3}$ catalyst which illustrate four significant weight lost curves which occurred at $80,130,250$ and $480{ }^{\circ} \mathrm{C}$.

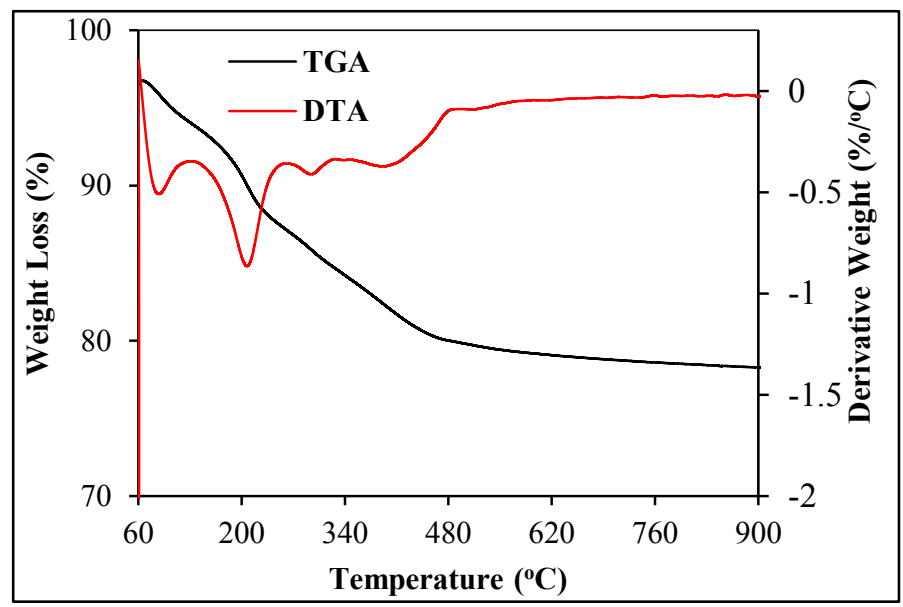

Figure 5. TGA-DTA thermogram of $\mathrm{Ce} / \mathrm{Al}_{2} \mathrm{O}_{3}$ catalyst after aging in an oven for 24 hours at $80-90{ }^{\circ} \mathrm{C}$.

The total weight loss for this sample is $16.69 \%$. Freewater molecule and nitrate compound was removed from the supported catalyst starting from a temperature of $80{ }^{\circ} \mathrm{C}$ until $340{ }^{\circ} \mathrm{C}$. Meanwhile at $480{ }^{\circ} \mathrm{C}$ onward; nitrate compounds and surface hydroxyl molecule were decomposed from the samples [9]. From this investigation, the calcination temperature of $400{ }^{\circ} \mathrm{C}$ is insufficient to remove all the nitrate compounds that originate from the metal precursor. This observation is in agreement with the results shown in "effect of different metal oxides and calcination temperatures of catalyst" in which using $\mathrm{Ce} / \mathrm{Al}_{2} \mathrm{O}_{3}$ catalyst calcined at $400{ }^{\circ} \mathrm{C}$, the TAN value of crude $\mathrm{B}$ cannot be reduced to lower than one as the catalyst calcined at this temperature resulted in incomplete formation of metal oxide.

\section{BET analysis}

One of the most characteristic properties of the surface of a solid is its ability to adsorb gases and vapors. The potential catalyst of fresh and spent $\mathrm{Ce} / \mathrm{Al}_{2} \mathrm{O}_{3}$ were characterized by nitrogen adsorption analysis. Table 1 summarizes their BET surface area and BJH desorption average pore diameter.

Table 1. BET surface area and BJH desorption average pore diameter of the fresh and spent forms of $\mathrm{Ce} / \mathrm{Al}_{2} \mathrm{O}_{3}$ catalyst

\begin{tabular}{lcc}
\hline Condition & SBET $\left(\mathbf{m}^{\mathbf{2}} \mathbf{g}^{-\mathbf{1}}\right)$ & Pore Diameter (A) \\
\hline Fresh & 70 & 19 \\
Used & 62 & 25 \\
\hline
\end{tabular}

Isotherm shape depends on the solid porous texture. Figure 6 shows the NA isotherm of fresh and used $\mathrm{Ce} / \mathrm{Al}_{2} \mathrm{O}_{3}$ catalyst. NA/desorption isotherm of $\mathrm{Ce} / \mathrm{Al}_{2} \mathrm{O}_{3}$ catalyst prepared exhibit the characteristic of mesoporous structure with Type IV with incorporation of some mesopores with the presence of hysteresis loop type H3. Results showed that the surface area of used catalyst $\left(70 \mathrm{~m}^{2} / \mathrm{g}\right)$ was slightly decreased than fresh $\mathrm{Ce} / \mathrm{Al}_{2} \mathrm{O}_{3}$ catalyst $\left(62 \mathrm{~m}^{2} / \mathrm{g}\right)$ probably due to some surface areas which were covered with contamination from crude oil during catalytic 
deacidification reaction. However, this occurrence does not affect the catalytic activity after using for one time as proved by catalytic deacidification in reusability testing.

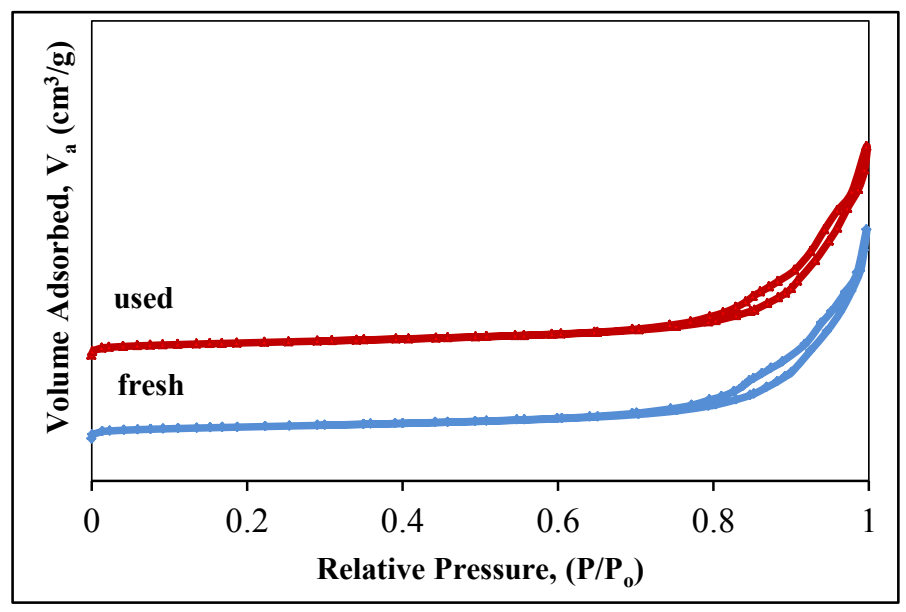

Figure 6. Nitrogen adsorption-desorption isotherms for fresh and used $\mathrm{Ce} / \mathrm{Al}_{2} \mathrm{O}_{3}$ catalyst

Figure 7 shows the pore size distribution curves of the fresh and used $\mathrm{Ce} / \mathrm{Al}_{2} \mathrm{O}_{3}$ catalyst calcined at temperature of $1000^{\circ} \mathrm{C}$. The pore size distributions calculated from the desorption branch by the Barret-Joyner-Halenda (BJH) method were very similar for both samples, presenting a very wide pore distribution covering the range of 19-40 nm.

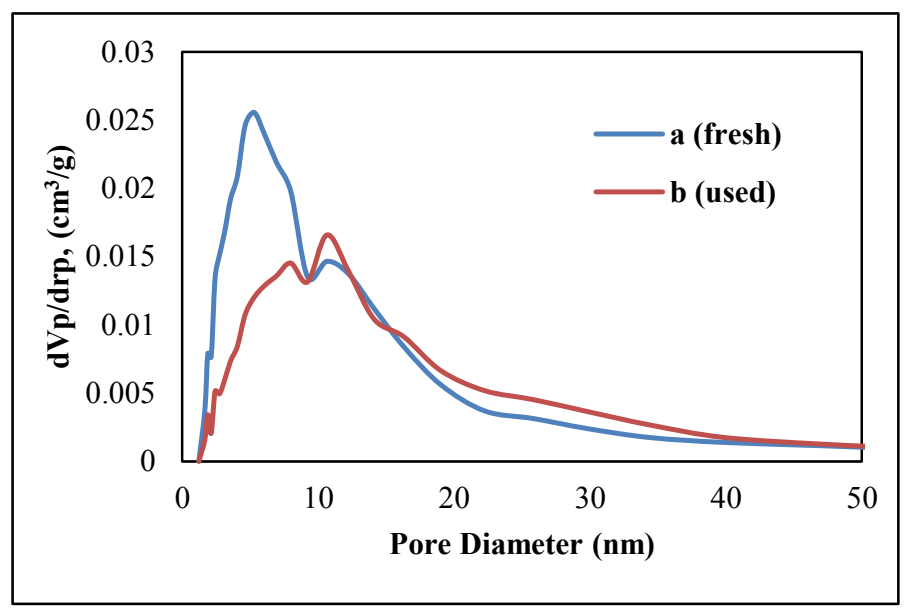

Figure 7. Pore size distribution of a) fresh and b) used $\mathrm{Ce} / \mathrm{Al}_{2} \mathrm{O}_{3}$ catalyst calcined at $1000{ }^{\circ} \mathrm{C}$ for 5 hours

\section{XRD analysis}

In order to confirm the reusability of the $\mathrm{Ce} / \mathrm{Al}_{2} \mathrm{O}_{3}$ catalyst, the diffractograms of fresh and used $\mathrm{Ce} / \mathrm{Al}_{2} \mathrm{O}_{3}$ catalysts, both calcined at $1000{ }^{\circ} \mathrm{C}$ for 5 hours are compared in Figure 8 to investigate any transformation that occurred on the surface of this catalyst before and after being used (after $1^{\text {st }}$ catalytic testing) in the catalytic deacidification process of crude $\mathrm{B}$. Both diffractograms displayed the polycrystallinity phase dominated by the $\mathrm{CeO}_{2}$ (fcc) species and some of the alumina orthorhombic (o) phase. The $\mathrm{CeO}_{2}$ species for both fresh and used catalysts showed $2 \theta$ valuesat 28.6, $47.5,56.5,32.9,76.6$ and $78.9^{\circ}$. Meanwhile the alumina orthorhombic phase occurred at $2 \theta$ of 67.3 and $36.5^{\circ}$. This data shows that no change in the diffractograms of both fresh and used catalysts occurs which indirectly prove that 


\section{Nurasmat et al: CHARACTERIZATION AND DEACIDIFICATION OF ACIDIC PETROLEUM CRUDE OIL UTILIZING METAL OXIDE CATALYST SUPPORTED ON ALUMINA AND AMMONIATED POLYETHYLENE GLYCOL SOLUTION}

the $\mathrm{Ce} / \mathrm{Al}_{2} \mathrm{O}_{3}$ catalyst possesses a higher thermal stability, smaller rate of deactivation and higher reusability.This is shown via the reusability testing, whereby the catalyst can be used up to the fifth cycle with an excellent catalytic deacidification activity.

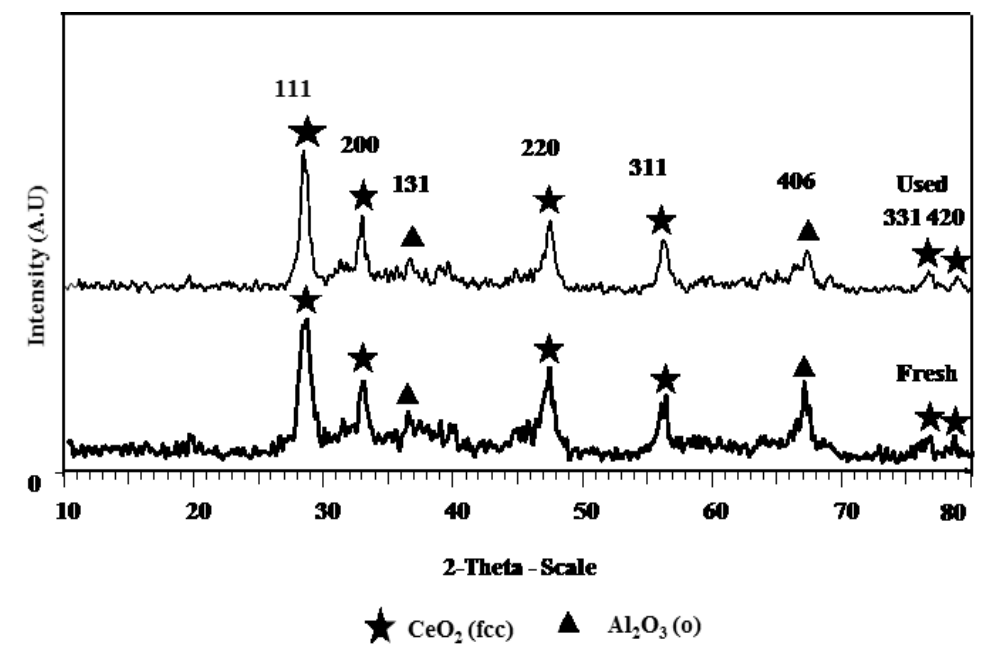

Figure 8. XRD diffractograms of fresh and used $\mathrm{Ce} / \mathrm{Al}_{2} \mathrm{O}_{3}$ catalysts calcined at $1000{ }^{\circ} \mathrm{C}$ for 5 hours

\section{Conclusion}

The technology applied was successful in meeting the PETRONAS benchmark of a TAN less than $1 \mathrm{mg} \mathrm{KOH} / \mathrm{g}$ for crude oil $\mathrm{B}$. The result from the catalytic deacidification process revealed that $\mathrm{Ce} / \mathrm{Al}_{2} \mathrm{O}_{3}$ catalyst prepared at a calcination temperature of $1000{ }^{\circ} \mathrm{C}$ has the potential to enhance the reduction of TAN in crude oil. Physical characterization by BET analysis showed that this catalyst has the largest surface area. This revelation is significant as a greater surface area offers more surface-active sites for catalytic deacidification to take place. Furthermore, XRD diffractograms portrayed unchanged composition after this catalyst is used in the catalytic deacidification reaction which indirectly proved that this catalyst possesses a higher thermal stability, smaller rate of deactivation and higher reusability.

\section{Acknowledgement}

The authors gratefully acknowledge Universiti Teknologi Malaysia (UTM), Ministry of Education (MOE), for the financial support given under Fundamental Research Grant Scheme (FRGS, Vote no.: 4F225) and Ministry of Science, Technology and Innovation (MOSTI) for MyBrain 15 scholarship to Nurasmat Mohd Shukri.

\section{References}

1. Slavcheva, E., Shone, B. and Turnbull, A. (1999). Review of naphthenic acid corrosion in oil refining. British Corrosion Journal 34(2): 125 - 131.

2. Brient, J. A., Wessner, P. J. and Doyle, M. N. (2000). Naphthenic Acids. In: Kirk-Othmer Encyclopedia of Chemical Technology. John Wiley and Sons, Inc.

3. Saad,O. M., Gasmelseed, G. A. and Hamid, A. H. M. (2014). Separation of naphthenic acid from Sudanese crude oil using local activated clays. Journal of Applied and Industrial Sciences, 2(1): 14 -18.

4. Halbert, T. R., Riley, K. L., Trachte, K. L. and Vannauker, D. L. (1999). Process for reduction of total acid number in crude oil. US Patent 5,910,242. pp. $1-6$.

5. Braccknell, S. N. D. and Osborne, C. G. (2002). Process for deacidifying a crude oil system.US Patent 6,464,859. pp. $1-6$.

6. Shi, L. J., Shen, B. X. and Wang, G.Q. (2008). Removal of naphthenic acids from Beijing crude oil by forming ionic liquids. Energy Fuels, 22: 4177 - 4181. 
7. Toemen, S. Bakar, W. A. W. A. and Ali, R. (2014). Investigation of $\mathrm{Ru} / \mathrm{Mn} / \mathrm{Ce} / \mathrm{Al}_{2} \mathrm{O}_{3}$ catalyst for carbon dioxide methanation: Catalytic optimization, physicochemical studies and RSM. Journal of the Taiwan Institute of Chemical Engineers, 45 (5): 2370 - 2378.

8. Ayastuy, J. L., Fernandez-Puertas, E., Gonzalez-Marcos, M. P. and Gutierrez-Ortiz, M. A. (2012). Transition metal promoters in $\mathrm{CuO} / \mathrm{CeO}_{2}$ catalysts for $\mathrm{CO}$ removal from hydrogen streams. International Journal of Hydrogen Energy, 37: 7385 -7397.

9. Alouche, A. (2008). Preparation and characterization of copper and/or cerium catalysts supported on alumina or ceria. Jordan Journal of Mechanical and Industrial Engineering, 2: 111 - 116. 